\title{
Where does implementation lie? Assessing the determinants of delegation and discretion in post-Maastricht European Union
}

\author{
Marta Migliorati* (1) \\ Jacques Delors Centre, Hertie School, Germany \\ *Corresponding author. E-mail: migliorati@delorscentre.eu
}

(Received 10 July 2019; revised 30 April 2020; accepted 01 May 2020; first published online 09 June 2020)

\begin{abstract}
Drawing on a principal-agent framework the article analyses the European Union (EU) politics of delegation in the post-Maastricht era. By means of statistical analysis, it tests the impact of several variables upon the selection of national and supranational agents, as well as on the discretion they enjoy, on the basis of a recently collected data set of EU laws. Findings reveal that pooling and policy complexity favour the involvement of supranational actors in the implementation of EU laws. Moreover, the degree of supranational integration of a policy affects the likelihood of choosing supranational implementers. On the one hand, the Commission enjoys higher discretion vis-à-vis national actors when qualified majority voting applies, and when higher levels of conflict in the Council of Ministers is present. On the other, conflict between the European Parliament and the Council under codecision seems associated with lower supranational discretion, although the result needs further corroboration.
\end{abstract}

Keywords: delegation; EU law; European Union; policy implementation; principal-agent

\section{Introduction}

Who has the power of implementing policies in the European Union (EU)? Answering this question is harder than it may seem at first sight. Along the past three decades, known as the "post-Maastricht" era, the EU system of governance has become essentially more complex and "multilevel" (Hooghe and Marks 2001, 2003; Scharpf 1997). While the EU legislative power is divided between the Commission (who initiates the legislation), the Council and the European Parliament (who negotiate the laws proposed by the Commission), laws are subsequently implemented at different levels and by different actors. They include national (public administration and independent regulatory authorities), supranational (the European Commission) "networked" (Levi-Faur 2011) and "de novo" (Bickerton et al. 2015) bodies (e.g. over

(C) The Author(s), 2020. Published by Cambridge University Press. This is an Open Access article, distributed under the terms of the Creative Commons Attribution licence (http://creativecommons.org/licenses/by/4.0/), which permits unrestricted re-use, distribution, and reproduction in any medium, provided the original work is properly cited. 
$34 \mathrm{EU}$ decentralised agencies and other institutions such as the European External Action Service and the European Stability Mechanism). ${ }^{1}$

The existence of different kinds of policy implementers in the EU opens puzzling questions including, on the one hand, why EU legislators select more or less supranational actors to implement policies (Delreux and Adriaensen 2018, p. 265). On the other, it leads to ask what determines the different degrees of executive leeway these actors enjoy vis-à-vis each other. Although, since the early 2000s, several scholars have sought to disentangle the dynamics underlying these phenomena, the rapidly evolving EU governance system makes this an increasingly intricate exercise.

With this article I employ a principal-agent (PA) framework to address the politics of executive delegation in the post-Maastricht era by addressing two main issues, that is, (a) what determines the choice of opting for delegation to national administrations, to the European Commission, EU agencies, or a combination of these actors and (b) what determines the degree of discretion enjoyed by the supranational level vis-à-vis the national one. By so doing, I contribute to the literature on EU public policy by providing an empirical overview of the distribution of implementation competences delegated in EU legislation without limiting it to the traditional Commission-national dichotomy but also grasping variation in between.

The remainder of this article is structured as follows. After a review of the state of the art on PA applied to the EU context, I outline the main PA relationships identifiable within the EU legislative process. I then specify five hypotheses accounting for different implementation choices and different degrees of discretion granted to implementers. I test my framework through ordered logistic and ordinary least squares (OLS) regression analyses. My findings show that decision rules and policy complexity favour the involvement of supranational actors (both agencies and the Commission) in the implementation of EU laws. Moreover, when codecision applies, the degree of supranational integration of a policy is associated with the likelihood of choosing supranational implementation in a curvilinear way. Regarding the agents' discretion, I find that the Commission enjoys higher discretion vis-à-vis national actors when qualified majority voting (QMV) applies, and when higher levels of conflict in the Council of Ministers are present.

\section{The PA framework: an overview}

According to the PA framework (for early work see Calvert et al. 1989; Epstein and O'Halloran 1994; McCubbins and Schwartz 1984; McCubbins and Sullivan 1987; Volden 2002), executive delegation occurs when legislators (the "principals") decide to give up a share of their responsibility to policy executors (the "agents") in order to implement policies. Political principals are willing to delegate executive tasks in order to reduce transaction costs (Pollack 1997) and overcome thorny issues such as the lack of policy efficiency and credible commitments (Majone 1997, 2001;

\footnotetext{
${ }^{1}$ According to Bickerton et al (2015), 'de novo bodies constitute a broad category inclusive of ' newly created institutions that often enjoy considerable autonomy by way of executive or legislative power' (p. 705)
} 
Thatcher 2002, 2011; Yesilkagit and Christensen 2010). In spite of the benefits of delegation, this action may produce agency losses from "shirking" due to diverging preferences between principals and agents and information asymmetries (Kiewiet and McCubbins 1991; Pollack 2003, 26-27; Thatcher 2011). Delegation, in fact, entails by definition, a risk of the principals to lose control over their agents, who in turn may defect and pursue their own agendas (agency drift, or slack), or simply fail to produce outcomes as good as if the principal had been in charge (agency loss). In order to minimise costs, therefore, delegation of any kind of authority must be accompanied by control mechanisms (Epstein and O'Halloran 1994). For this reason, the PA framework is not limited to theorising the act of delegation but also outlines the dynamics underlying the agents' discretion, that is, "the leeway conferred to an agent to accomplish a delegation mandate" (da ConceiçãoHeldt 2017, p. 204). Political principals can exert control ex ante by limiting the flexibility of the agents' actions (da Conceição 2010; McCubbins and Schwartz 1984; McCubbins et al. 1989) and by imposing procedural constraints within the legislation (Franchino 2007).

The EU is a prolific testing ground for the PA approach as the process of EU integration has involved a remarkable transfer of tasks from the EU legislative bodies to both national and supranational executors in comparison to traditional international organisations (Hooghe and Marks 2015). Yet, being a system of "multilevel governance" (Hooghe and Marks 2001, 2003; Scharpf 1997), the EU displays multiple chains of delegation (Bergman 2000; Curtin 2009; Nielson and Tierney 2003) through which different legislative bodies delegate executive tasks to multiple actors. These features make, on the one hand, the PA framework a valuable "toolkit", helpful to disentangle several questions related to the distribution of power and competences in the EU (Delreux and Adriaensen 2018; Egan et al. 2017). On the other, they constrain the applicability of the model as the individuation of delegation relations may be harder than in the presence of less actors in the institutional landscape (Delreux and Adriaensen 2017, 2018; Kassim and Menon 2003). In spite of these limitations, research applying PA to the EU is vast. Several scholars have focused on delegation to traditional supranational institutions such as the European Commission (Franchino 2002, 2007) and the European Court of Justice (Tallberg 2002) but also on member states' relations with other institutions such as the Council Presidency or the European Central Bank (Elgie 2002; Thatcher and Sweet 2002). Scholars have also sought to focus on inter-institutional interaction between the European Council and the Council of the European Union (Kroll 2017), on delegation to scientific committees (Dunlop and James 2007) and to comitology committees (Moury and Héritier 2012). Moreover, PA has been applied to specific policy areas such as negotiations in trade (Gastinger and Adriaensen 2019; Kerremans 2004) and environmental policies (Delreux 2009).

As far as the process of delegation in EU secondary laws is concerned, the first theoretical and empirical attempt to assess it on a relatively large sample is Franchino's seminal work, "The powers of the Union" (2007). Thomson and Torenvlied (2011) provided a similar contribution, concentrating on the period between 2000 and 2005. Ershova (2019), in turn, analysed delegation to the European Commission during Barroso II and Junker's leaderships, while Migliorati (2019) tackled delegation to EU agencies between the mid-1980s and 2016. 
Against the background just overviewed, a contribution providing an encompassing picture of delegation to supranational actors and the discretion they enjoy across policy area in the post-Maastricht era is still missing.

\section{An empirical mapping of delegation paths and agents' discretion in EU secondary law}

According to Delreux and Adriaensen, the PA approach is useful in the EU context to carry out three main tasks, that is, "mapping principal-agent relations; studying the politics of delegation; and studying the politics of discretion" (2017, p. 14). In this section, I draw the main PA relationships that are empirically identifiable in EU secondary law on the basis of a pre-existing data set covering the period between 1985 and 2016 (Migliorati 2019). After that, on the basis of the same data, I measure the degree of discretion granted to national and supranational agents.

To proceed with the empirical analysis, some premises are necessary. First of all, investigating delegation in secondary legislation is less straightforward than in primary law. While treaties limit to set general competences and decision rules through inter-state bargaining, secondary law is much more fine-grained and involves different decision-making rules. Legislation can be adopted either by the Council alone or jointly by the Council and the European Parliament under a proposal of the Commission. Laws can be adopted by unanimity or QMV (in the Council), depending on the procedure. With the Lisbon Treaty (2009), codecision became the EU's "ordinary legislative procedure" (OLP) making most of legislative files subject to QMV. There are still several exceptions including taxation, social security, the accession of new countries to the EU, foreign and common defence policy and operational police cooperation between EU countries, which are still voted by unanimity. When the Council legislates by itself, it is the only legislative body able to make delegation choices and therefore the only actual principal. Conversely, when the European Parliament and the Council legislate together under codecision, they represent a "collective principal" (Delreux and Adriaensen 2017; Nielson and Tierney 2003).

When (the) principal(s) decide(s) to delegate to national and/or supranational actors, this constitutes "an active choice between alternative governance structures" (Tallberg 2002, p. 25). Implementation tasks may be left in the hands of national administrations or, conversely, be delegated entirely to the supranational level by employing the European Commission as the sole policy executor. Moreover, legislators may opt for an implementation path based on the relative reliance on these types of bureaucratic actors (Franchino 2007, p. 20), in which tasks are shared among the Commission and national administrations. Finally, legislators can also opt for an intermediate degree of supra-nationalisation by relying on the help of EU decentralised agencies (Busuioc and Groenleer 2013; Chiti 2004; Egeberg and Trondal 2017; Levi-Faur 2011; Majone 1994) that broadly represent a secondbest design choice to further delegation to the Commission (Kelemen and Tarrant 2011), and other de novo bodies (Bickerton et al. 2015; Fabbrini and Puetter 2016). In the case of agencies, according to a "double-delegation" logic (Eberlein and Grande 2005; Michaelowa et al. 2018), the Commission may be 
Table 1. Examples of implementation paths

\begin{tabular}{|c|c|c|}
\hline Implementation Path & Description & Example \\
\hline National & $\begin{array}{l}\text { National administrations are } \\
\text { mainly in charge of policy } \\
\text { execution }\end{array}$ & $\begin{array}{l}\text { Directive } 2008 / 104 / E C \text { of the } \\
\text { European Parliament and of the } \\
\text { Council of } 19 \text { November } 2008 \text { on } \\
\text { temporary agency work }\end{array}$ \\
\hline $\begin{array}{l}\text { Shared (National }+ \\
\text { Commission) }\end{array}$ & $\begin{array}{l}\text { National Administrations and } \\
\text { Commission share executive tasks }\end{array}$ & $\begin{array}{l}\text { Council Regulation (EC) No } 1407 / \\
2002 \text { of } 23 \text { July } 2002 \text { on State aid } \\
\text { to the coal industry }\end{array}$ \\
\hline $\begin{array}{l}\text { Shared (National+ } \\
\text { Commission }+ \text { agencies) }\end{array}$ & $\begin{array}{l}\text { National administrations share } \\
\text { executive tasks with the } \\
\text { Commission and EU agencies }\end{array}$ & $\begin{array}{l}\text { Regulation (EC) No } 1907 / 2006 \text { of } \\
\text { the European Parliament and of } \\
\text { the Council of } 18 \text { December } 2006 \\
\text { concerning the Registration, } \\
\text { Evaluation, Authorisation and } \\
\text { Restriction of Chemicals (REACH), } \\
\text { establishing a European } \\
\text { Chemicals Agency, amending } \\
\text { Directive } 1999 / 45 / E C \text { and } \\
\text { repealing Council Regulation (EEC) } \\
\text { No } 793 / 93 \text { and Commission } \\
\text { Regulation (EC) No } 1488 / 94 \text { as } \\
\text { well as Council Directive } 76 / 769 / \\
\text { EEC and Commission Directives } \\
\text { 91/155/EEC, 93/67/EEC, 93/105/EC } \\
\text { and 2000/21/EC }\end{array}$ \\
\hline Supranational & $\begin{array}{l}\text { The European Commission is in } \\
\text { charge of policy execution }\end{array}$ & $\begin{array}{l}\text { Council Regulation (EEC) No 3976/ } \\
87 \text { of } 14 \text { December } 1987 \text { on the } \\
\text { application of Article } 85 \text { (3) of the } \\
\text { Treaty to certain categories of } \\
\text { agreements and concerted } \\
\text { practices in the air transport } \\
\text { sector }\end{array}$ \\
\hline
\end{tabular}

considered a principal too, given that agencies are often treated as an expansion of the EU administrative apparatus (Egeberg and Trondal 2017). ${ }^{2}$

Examples of the four detected paths are provided in Table 1: for instance, legislation on temporary agency work leaves implementation in the hands of national administrations, while competition in the air transport sector is entirely delegated to the Commission. Since 2006, regulation of chemical products in the Union is shared between the Commission, national regulatory authorities and the European Chemicals Agency.

The coding of delegation consists of a textual analysis performed following Franchino's approach (2007). The method has been used by other authors including Ershova (2019), Pollack (2003), Thomson and Torenvlied (2011), and Epstein and O'Halloran (1999). Once identified provisions within the legislative text, I code whether legislative provisions delegate implementation powers to national

\footnotetext{
${ }^{2}$ Delegation choices in secondary legislation, specifically, are partially constrained by treaty laws. In fact, after the Lisbon Treaty, a division of competences was set such that there are areas of "exclusive" EU competences, "shared" and exclusive national. However, the division does not signify that, for example, in an area of exclusive EU competences, the national level is completely left out.
} 


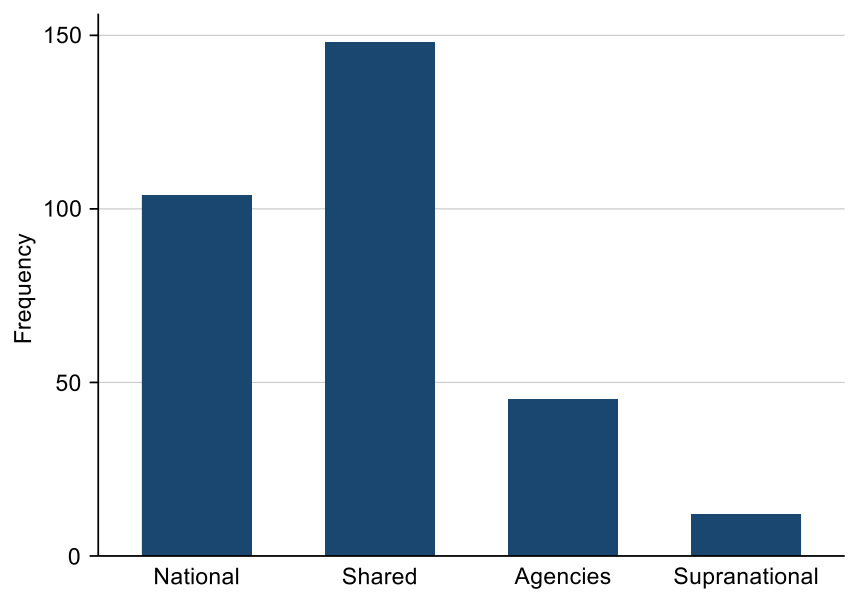

Figure 1. Implementation paths in the dataset.

administrations and the Commission. For example, provisions specifying that member states may, or are entitled to, take some action, or that they are exempted from certain aspects of the law, delegate to national administrations. Conversely, acts letting the Commission adopt decisions, set guidelines and standards, request actions, or authorise action of other actors, delegate to the Commission.

Finally, if an agency is included in the act for the purpose of policy implementation, delegation to agencies is coded as present. Other de novo bodies are excluded from coding as they are either absent (e.g. the European External Action Service) or present only in a small number of cases (e.g. the European Central Bank). ${ }^{3}$

Completely, national delegation is present when only national delegation is higher than 0 . The first degree of shared delegation occurs when both national and Commission delegation are higher than 0 , but no agency is involved. The second degree of shared path occurs when both Commission and national delegation are higher than 0 , and an agency is involved in implementation. Finally, the path is supranational when national delegation is equal to 0 and the Commission delegation ratio is higher than 0 . The bar chart in Figure 1 shows the frequency of each category present in the data set. Shared powers by Commission and national administration are the most frequent one, followed by the fully national path. The third (agencies involvement) and fourth paths are less frequent. Table 2, in turn, shows the share of each category within the broad policy categories (Leuffen et al. 2013).

And yet, the choice of delegation is just half the story. As noted before, the concept of delegation goes hand in hand with the degree of discretion granted to the executors. Indeed, delegation is usually accompanied by the establishment of several control mechanisms so as to prevent agency losses (Gastinger and Adriaensen 2019). Hence, even if supranational actors are indeed involved in the implementation process, they may be substantially more constrained than national ones. The degree of national administrations' and the Commission's discretion is obtained by weighting the delegating provisions

\footnotetext{
${ }^{3}$ More details on the coding are included in the Appendix due to space limitations.
} 
Table 2. Implementation paths and policy areas

\begin{tabular}{|c|c|c|c|c|c|}
\hline & \multicolumn{4}{|c|}{ Delegation Path } & \multirow[b]{2}{*}{ Tota } \\
\hline & $\begin{array}{c}1 \\
\text { (National) } \\
\end{array}$ & $\begin{array}{c}2 \\
\text { (Shared) } \\
\end{array}$ & $\begin{array}{c}3 \text { (Shared with } \\
\text { Agencies) }\end{array}$ & $\begin{array}{c}4 \\
\text { (Supranational) } \\
\end{array}$ & \\
\hline \multicolumn{6}{|l|}{ Policy (broad categories) } \\
\hline Agriculture & 0 & 5 & 0 & 0 & 5 \\
\hline Civil & 19 & 1 & 0 & 0 & 20 \\
\hline Competition and industry & 4 & 9 & 1 & 1 & 15 \\
\hline Economic external relations & 1 & 2 & 0 & 0 & 3 \\
\hline Economic freedoms & 5 & 10 & 2 & 0 & 17 \\
\hline Energy and transport & 4 & 21 & 6 & 4 & 35 \\
\hline $\begin{array}{l}\text { Environment consumer } \\
\text { protection }\end{array}$ & 17 & 58 & 21 & 2 & 98 \\
\hline Labour & 12 & 3 & 0 & 1 & 16 \\
\hline Macroeconomic & 12 & 16 & 6 & 2 & 36 \\
\hline Monetary policy & 1 & 3 & 2 & 0 & 6 \\
\hline Research and development & 4 & 8 & 3 & 0 & 15 \\
\hline Security & 17 & 7 & 4 & 2 & 30 \\
\hline Tax & 4 & 3 & 0 & 0 & 7 \\
\hline Welfare & 4 & 2 & 0 & 0 & 6 \\
\hline Total & 104 & 148 & 45 & 12 & 309 \\
\hline
\end{tabular}

by the constraints imposed on implementers (measurement details for constraints in the Appendix). ${ }^{4}$ Histograms in Figures 2 and 3 show, respectively, the distribution of national and supranational (Commission) discretion. In 30 cases of 309, national discretion is equal to 0 , while in 107 cases of 309 , the Commission's discretion is equal to 0 . The two graphs show that national discretion is, overall, comparatively twice as high as the Commission's, and that both distributions are skewed towards 0 .

In order to collapse the two ratios into a single measurement, I compute the relative discretion between the Commission and the national administrations, that is, the extent to which the Commission enjoys executive leeway vis-à-vis national administrations. I do this by calculating the difference between the Commission discretion ratio and the national discretion ratio (Franchino 2007), shown in Figure 4.

The empirical evidence just overviewed confirms the existence of a strong variation among both implementation paths and discretion levels. In the next section, I draw five hypotheses accounting for the differences just outlined.

\section{Determinants of delegation paths Decision rules}

I hypothesise that the first factor affecting the likelihood of involving the supranational level in policy implementation is linked to the utilisation of QMV in the

\footnotetext{
${ }^{4}$ It is hardly possible to measure the level of discretion granted to agencies in secondary law, as they are often just mentioned in the legislative act while constraints and tasks are specified in their founding act.
} 


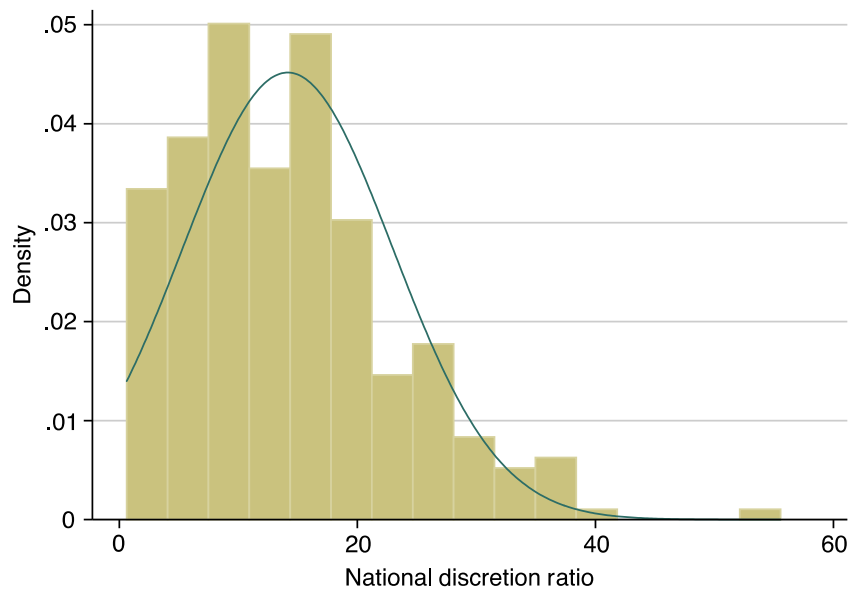

Figure 2. Distribution of national discretion ratio.

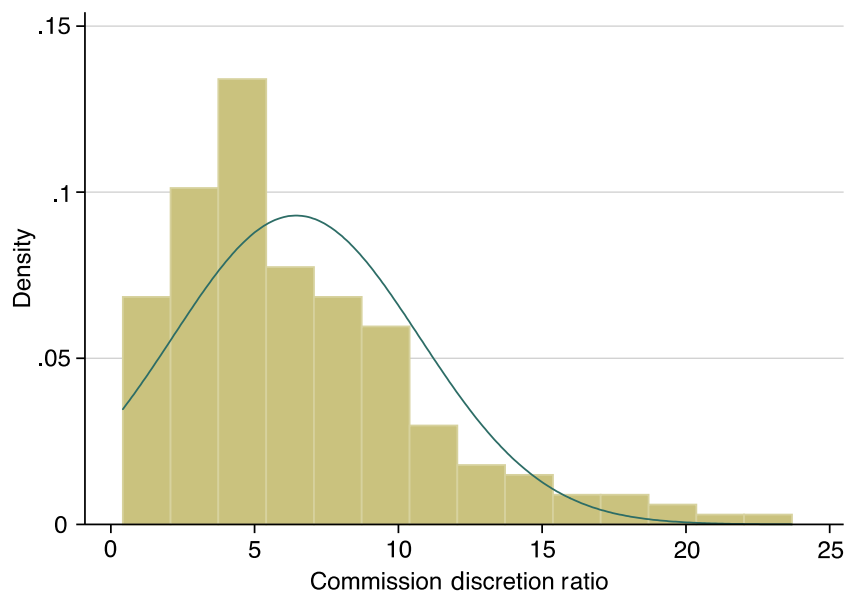

Figure 3. Distribution of Commission's discretion ratio.

Council of Ministers, regardless of the involvement of the European Parliament. Pooling, that is the choice of states to "transfer the authority to make binding decisions from themselves to a collective body of states within which they may exercise more or less influence" (Hooghe and Marks 2015, p. 308), supposedly affects delegation choices because it "not only makes the formal decision-making of any single government more dependent on the votes of its foreign counterparts, but also more dependent on agenda-setting by the Commission" (Moravcsik 1993, p. 509). According to Franchino, delegation of executive tasks to the Commission by the Council is more likely under QMV than unanimity, because the Commission can take advantage of different preferences in the Council and make winning proposals that delegate more powers to the supranational executive and restrain further national administrative autonomy. In addition, pivotal ministers in majority voting 


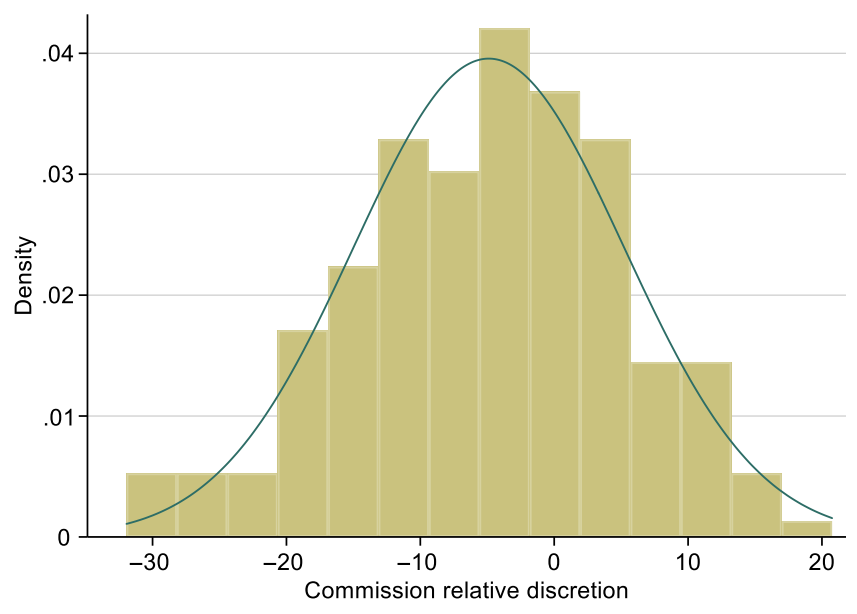

Figure 4. Distribution of Commission's relative discretion.

are likely to have more moderate preferences and they are also likely to prefer lower national executive discretion and/or delegation to the Commission (Franchino 2007, p. 22). In sum, the Commission should have more leverage under QMV as it has to convince less (and less hostile) actors in order to obtain a policy closer to its preferences, that is, delegating to itself or, as a second choice, to EU decentralised agencies (Kelemen and Tarrant 2011). It follows that it should be more likely to observe a higher frequency of delegation to supranational actors under qualified majority than under unanimity.

H1: QMV increases the probability of delegation to the supranational level.

\section{Policy complexity}

The second argument accounting for the selection of a more supranational path derives from a functional logic connected, on the one hand, to principals' transaction cost calculations and, on the other, to the multi-level structure of EU governance. Several scholars have underlined that poorly informed politicians tend to rely more on the expertise of implementers (Epstein and O' Halloran 1999; Elgie and McMenamin 2005; Majone 2001; Thatcher 2002; Wonka and Rittberger 2010). It is sensible for a legislator to delegate the burden of implementing policies requiring high levels of expertise, especially if implementers are better informed about the effects of European policies than are policymakers themselves. On top of that, with the emergence of a multi-level system characterised by high interdependence and dialogue across different governance levels, it has been observed how the EU tends to increasingly rely on network structures (Levi-Faur 2011) orchestrated by the Commission (Blauberger and Rittberger 2015; Migliorati 2017) and facilitating best practices and diffuse expertise, and on EU-level agencies to deal with complex policy issues (Migliorati 2019; Wonka and Rittberger 2010). This evidence suggests that the post-Maastricht scenario is increasingly characterised by the need to rely not only 
on national implementers, but also on supranational ones, when issues become more complex and encompass multiple policy dimensions. Being a functional logic of delegation based on the need of principals to acquire as much expertise as possible, it should apply both when the European Parliament is involved and when it is not.

H2: Higher policy complexity increases the probability to rely on multiple levels of governance and, therefore, on supranational implementers

\section{Supranational integration}

Tallberg (2002) maintains that delegation dynamics in the EU present "feed-back loops". According to this view, future delegation choices are affected by previous ones (see also Thatcher 2011). Given that supranational institutions have been increasingly granted competences through the EU treaties (Börzel 2005; Leuffen et al. 2013), it is reasonable to expect secondary law to be more likely to grant more implementation tasks to supranational actors when integration at the supranational level is higher. Ripoll Servent argues that in the EU, "power is usually not delegated horizontally but vertically" (Ripoll Servent 2018, p. 5). This implies that delegating tasks to the Commission and to agencies is often preceded by a transfer of competences to the EU level.

However, there are reasons to expect that such an upward trend may be interrupted by a countervailing mechanism specific to the post-Maastricht era: Bickerton et al. (2015) and Fabbrini and Puetter (2016) argue that since the early 1990s, the EU has witnessed a process of "integration without supranationalisation" characterised by the reluctance of EU member states to further delegate tasks to the supranational level beyond a certain level. Cases in point are the area of justice and home affairs (Maricut 2016) and energy policies (Thaler 2016).

Against this background, I argue that the degree to which a policy is integrated at the EU level should be associated with an increasing probability of involving supranational actors in subsequent processes of policy implementation. The probability may start declining after a certain threshold, due to the reluctance of member states to delegate further competences to supranational actors. As the European Parliament is generally assumed to prefer delegation to EU actors (Kelemen and Tarrant 2011), it may be the case that legislation adopted under codecision has a stronger positive effect on delegation to the supranational level than laws adopted by the Council alone.

H3: the higher the degree of supranational integration and competence transfer to the supranational level, the more likely the involvement of more supranational actors in policy implementation. However, the trend should invert for high levels of integration producing a curvilinear development.

\section{Determinants of varying discretion levels: decision rules and conflict}

Extensive research has been conducted to assess the factors that trigger principals' control and, consequently, affect agents' discretion. Research along these lines focuses especially on the effects of decision rules (Franchino 2007; Thomson and Torenvlied 2011) and the preference heterogeneity among principals (da Conceição 2010; da Conceição-Heldt 2017; Elsig 2010; Epstein and O’Halloran 
1994; Franchino 2007; Hawkins et al. 2006; Martin 2006; Schneider and Tobin 2013). On the basis of this literature, I draw two main expectations.

First of all, by essentially the same mechanism described in the previous theoretical section, as much as QMV allegedly affects the choice of the implementation path, it should also be able to facilitate higher discretion levels granted to the supranational level.

H4: QMV grants relatively higher discretion to the Commission than to national administrations.

Second, according to previous literature, one of the most important factors shaping agents' discretion seems to be the preference heterogeneity between principals. Back in the 1990s, Epstein and O' Halloran (1999) were the first to show that with divided governments, the Congress gives up more executive discretion to independent regulatory agencies, rather than to bureaucratic departments. By a similar token, Franchino (2007) showed how the relative discretion granted to the Commission compared to national administrations increases as the conflict among Council members increases; and, more recently, da Conceição (2010) and Elsig (2010) proved empirically that the preference heterogeneity of the principals increases the agents' discretion.

The underlying argument linking conflict to discretion is that, in the presence of conflict, principals would rather grant higher discretion in policy implementation to a more impartial supranational executor, that is, the Commission, instead of risking to incur in losses provoked by other states' implementation deficits (Tallberg 2002, p. 25). In additional support to this view, a commitment component exists: for example, when conflict among Council members is high, member states' governments are more likely to face commitment problems, because preference divergence makes the strength of their policy commitments much looser (Thomson and Torenvlied 2011). The act of self-commitment, in sum, "is only meaningful to the extent that supranational agents enjoy extensive discretion in the execution of their functions and do not face the immediate threat of having their decisions overturned by government principals" (Tallberg 2002, p. 29). In presence of conflict, delegation of higher discretion to the Commission would be, therefore, preferable rather than national administrations, because it protects states from each others' defections and ensures the credibility of the commitments taken.

The mechanisms just overviewed relate mainly to a situation in which the Council is the only principal. When it comes to dealing with the role of the European Parliament, there are very few contributions available. According to recent work by Conceição-Heldt (2017), preference homogeneity between states and the Parliament in trade policy results in lower discretion to the Commission, as more cohesive principals are more successful in presenting a unified front vis-à-vis their agent.

Against this background, I draw a general hypothesis on the relationship between conflict and discretion:

H5: The higher the preference heterogeneity of principals, the higher the discretion granted to the supranational level.

Table 3 summarises the hypotheses outlined so far. 
Table 3. Summary of main hypotheses and mechanisms

\begin{tabular}{|c|c|c|}
\hline \multicolumn{3}{|c|}{ Choice of the Implementer - from National to Supranational Delegation Path } \\
\hline Hypothesis & Mechanism & Relationship \\
\hline Hypothesis 1: QMV & $\begin{array}{l}\text { Less extreme preferences, more Commission bargaining } \\
\text { power }\end{array}$ & + \\
\hline Hypothesis 2: Complexity & $\begin{array}{l}\text { Complex issues require high specialisation and increasingly } \\
\text { call for the involvement of both national and } \\
\text { supranational actors }\end{array}$ & + \\
\hline $\begin{array}{l}\text { Hypothesis 3: } \\
\text { Supranational integration }\end{array}$ & $\begin{array}{l}\text { Path dependence, previous delegation, integration without } \\
\text { supranationalisation }\end{array}$ & Curvilinear \\
\hline \multicolumn{3}{|c|}{ Relative Discretion - More or Less Supranational } \\
\hline Hypothesis & Mechanism & Relationship \\
\hline Hypothesis 4: QMV & $\begin{array}{l}\text { Less extreme preferences, more Commission bargaining } \\
\text { power }\end{array}$ & + \\
\hline $\begin{array}{l}\text { Hypothesis } 5 \text { : Conflict } \\
\text { among principals }\end{array}$ & $\begin{array}{l}\text { Credibility of commitments, protecting agreements from } \\
\text { other states' defection, unitary front in case of low conflict }\end{array}$ & + \\
\hline
\end{tabular}

\section{Measurement (independent variables) ${ }^{5}$ \\ Complexity}

The operationalisation of policy complexity is notably cumbersome. As far as EU legislative studies are concerned, a number of scholars (Franchino 2002, 2007; Kaeding 2006; Migliorati 2019; Rasmussen and Reh 2013; Thomson and Torenvlied 2011) have employed the number of recitals included in the legislative acts. ${ }^{6}$ A large number of recitals indicate that the directive has an extensive scope as well as addressing a high number of important issues and the overall more complex policy areas (Toshkov 2008). Although such measurement may also hint at the scope of a proposal, its salience and/or controversy (Ershova 2019; Warntjen 2012), given the widespread use of recitals as a proxy of complexity, I assume a good degree of reliability for this measurement. Yet, to better grasp the multi-dimensionality of a policy, I also employ the number of definitions included by the EuroVoc dictionary in the Eurlex database. EuroVoc is a multilingual, multidisciplinary thesaurus covering the activities of the EU. For example, Directive 2009/73/EC of 13 July 2009, concerning common rules for the internal market in natural gas includes 10 different terms ranging from consumer protection to gas supply, while Directive 2008/48/EC on credit agreements for consumers has only 4 terms. By measuring the amount of specific terms associated with each legislative act, this variable should be able to grasp not only the absolute complexity of the act but also the amount of policy dimensions it encompasses.

\footnotetext{
${ }^{5}$ For the operationalisation of the DVs, please refer to previous section and Appendix

${ }^{6}$ Recitals precede the body of the act and give the reasons for the contents of the enacting terms (i.e. the articles).
} 


\section{Conflict}

Several scholars have argued that the EU policy space is multi-dimensional (see Hix and Høyland 2011). The three most important ones acknowledged by the literature are the integration dimension, the left-right dimension and the policy dimension. Some studies have considered all of them (e.g. Franchino 2007), while others, such as Crombez and Hix (2015), simplify the multi-dimensionality argument and employ just the left-right dimension, arguing that it is reasonable to assume that politicians' preferences on EU policies are influenced by their underlying left-right preferences and by their actual policy preferences (Crombez and Hix 2015). In order to make the analysis as encompassing as possible, I employ both the left-right and the integration dimensions. I calculated the left-right position of each government drawn from the Parlgov data set (Döring and Manow 2012) at the time of legislative adoption, by weighting the left-right score of each party sitting in the government by the share of seats it holds in the national parliament. I then measured the right-left range among Council member governments by calculating the absolute difference between the extreme right and the extreme left government position in the Council (under unanimity rule), and the absolute difference between the right and left pivots (under QMV), at the time of adoption. In a onedimensional setting, there are two pivotal states, one for the leftward move (the most left-wing member among the right-wing) and one for the rightward move (the most right-wing member among the left-wing ones. To identify, respectively, the right and left pivots, I employ the codebook of the Comparative Manifesto Project (CMP) in order to match policy categories and corresponding leftward and rightward shifts. I apply a matching similar to Franchino (2007) and Ershova (2019). For example, I match the "Water framework directive", which aims at the prevention of water pollution, with the category "Environmental Protection", which is recognised as being a priority for left-wing parties. In this case, therefore, more environmental protection implies a leftward shift: The pivotal actor in this instance was Belgium. I followed a similar procedure to calculate conflict along the integration dimension through the Parlgov data set. Assuming that passing EU legislation generally implies a shift towards higher integration, the integration pivot is the least integrationist among the prointegration Council members. Using the Parlgov data set, I also calculate the position of the European Parliament following Crombez and Hix (2015), thereby taking the score of the left-right and integration position of the median European Parliament (EP) group at each time of adoption. I then obtain the absolute value of the difference between the median EP (across integration and left-right dimensions) and the Council pivot.

\section{Decision rules}

I created a dichotomous variable taking the value of 1 when qualified majority applies (QMV) and 0 for unanimity (U). The majority (85\%) of legislation in the sample is adopted by QMV. The rest ( $15 \%)$ is adopted by unanimity.

\section{Supranational integration}

The balance of policy authority between the EU and the national levels has primarily been investigated through case studies, focusing on individual treaty effects or the effects of secondary legislation (Featherstone and Radaelli 2003; Saurugger and 
Radaelli 2008). Moreover, Börzel (2005) has mapped policy integration in the EU, considering the level and scope of integration; while Hix and Høyland (2011) show how different treaties have modified the competences and the decision-making process in the EU. Finally, Leuffen et al. (2013) calculated the evolution of formal, treaty-based authority over time in different fields of EU governance which, in turn, builds on Lindberg (1970) and Börzel's breadth and depth conceptualisation (2005). They distinguish between levels of authority ranging from 0 to 5 and including the following dimensions: No coordination at the EU level. Unanimous intergovernmental coordination without the involvement of supranational institutions; unanimous intergovernmental cooperation with limited involvement of supranational institutions; joint decisionmaking by majority with limited involvement of the EP; joint decisionmaking by majority with EP involvement and supranational centralisation. Given that this is the most recent policy-specific measurement of integration collapsed into one single dimension, I employ this measurement for my analysis.

\section{Controls}

Contrary to Thomson and Torenvlied (2011), I do not include a control variable differentiating directives from regulations. The relationship between executive discretion and type of legislative act is typically endogenous: regulations are directly applicable to national jurisdictions, while directives require the adoption of new legislation at the national level. Given that regulations are implemented at the supranational level, the Commission is by definition typically more constrained by the legislators, while directives are implemented at the national level, which implies that more detailed constraints are not necessary. I opted, instead, to control for acts which amend from those which introduce completely new laws, because when a provision is completely new, the impact of the Council's preferences should be higher as the implementers' discretion starts from 0 , while in the case of amending acts, we start from a different status quo in which the Commission and national administrations may already have some leeway secured by previous acts. I control for treaty fixed effects as there might be systematic changes associated with the adoption of a new treaty, and I distinguish between policies dealing with economic and social regulation (Wonka and Rittberger 2010). Finally, I control for policy salience through the Comparative Agenda Project Council Conclusions (Wilkerson et al. 2009), as the literature presents contradicting expectations in this regard. According to Rittberger et al. (2017), major media outlets tend to frame political responsibility for policy failures against the actor which is in charge of the implementation of a policy. Considering the increasing politicisation of EU integration (Hartlapp et al. 2014; Hooghe and Marks 2009; Rauh 2019), it may be the case that the logics of delegation themselves in the EU are influenced by this pattern: in particular, the unpopularity of certain policy decisions may result in higher levels of discretion to the Commission or to EU agencies. A countervailing logic supported by Calvert et al., (1989) and more recently Ershova (2019), on the other hand, links salience to lower supranational delegation and discretion. I also control for interinstitutional conflict (Ershova 2019) through the inclusion of early agreements under codecision and the distance of preferences between the median Commissioner and the 
pivotal Council member under other procedures. Summary statistics of all main variables of interest are displayed in Table 4.

\section{Analyses}

\section{Determinants of delegation paths}

I test my first three hypotheses (Hypotheses 1 to 3) relating to the choice of the delegation path by means of an ordered logistic regression model, as my dependent variable is an ordered categorical variable ranging from completely national implementation (1) to completely supranational implementation (4). I insert one interaction term for the curvilinear hypothesis.

I specify three models: the first includes all laws. The second only laws where the Council is the only principal and the third only laws adopted under codecision. The results are displayed in Table 5.

The effect of QMV is strong when all laws are included (Model I): On average, the probability of observing a fully national implementation path decreases by 20 percentage points under QMV than unanimity. Conversely, the probability of observing an implementation path shared between national administrations and the Commission increases by 20 percentage points under QMV compared to unanimity, the implementation path involving agencies by 14 percentage points and the completely supranational path by about 2 percentage points. The effect loses statistical significance in Model II. This may be due to the considerably smaller sample size and to the strong effect of salience in this subsample (see below).

Both complexity measurements yield significant and robust results in Models I and III, in line with Hypothesis 2, while it is not significant in Model II. On average, as shown in Figure 5, more complex laws are more likely to involve the supranational level and twice as less likely to involve only the national level (outcome 1). The effect is more significant for the traditional measurement of complexity (i.e. the number of recitals in the legislative act), while the measurement grasping multidimensionality has lower significance.

Regarding the level of supranational integration, the results corroborate Hypothesis 3 only for laws adopted under codecision. Figure 6 visualises the results.

The effect is particularly marked in the case of outcome 1 (national implementation), indicating that a completely national implementation path is extremely likely (96\% probability) in case of no supra-nationalisation, less so for medium levels of integration ( $26 \%-18 \%$ probability) and more likely for high integration levels. On the contrary, the other three paths display the opposite trend, characterised by low probabilities for low integration levels, higher in the middle and low again for very high integration levels. This is particularly marked in the case of agencies' involvement, as probability with low integration is very close to 0 , while it reaches $23 \%$ for medium integration levels. In the case of the Commission, the trend is less visible as the outcome is not very frequent. Yet, probability goes from 0 to 3.5 and then decreases to 0 again.

Among the control variables, an interesting finding relates to salience. While it does not have any significant effect on Models I and III, it displays a strong and highly 
Table 4. Summary statistics of main dependent and independent variables

\begin{tabular}{|c|c|c|c|c|c|c|}
\hline & Description & Obs. & Mean & SD & Min & $\operatorname{Max}$ \\
\hline DV1: Delegation Path & $\begin{array}{l}\text { Categorical, ordinal variable taking the value of } 1 \text { if delegation is } \\
\text { completely national and } 4 \text { if it is completely supranational }\end{array}$ & 309 & 2.43 & 1.10 & 1 & 4 \\
\hline National discretion & $\begin{array}{l}\text { National discretion ratio: Delegation ratio minus the constraint ratio } \\
\text { weighted by the value of the delegation ratio }\end{array}$ & 309 & 12.77 & 9.38 & 0 & 55.55 \\
\hline Commission discretion & $\begin{array}{l}\text { Commission discretion ratio: Delegation ratio minus the constraint ratio } \\
\text { weighted by the value of the delegation ratio }\end{array}$ & 309 & 4.21 & 4.63 & 0 & 23.68 \\
\hline DV2:Commission relative discretion & $\begin{array}{l}\text { Difference between the Commission's discretion ratio and national } \\
\text { discretion ratio }\end{array}$ & 309 & -8.56 & 11.56 & -55 & 20 \\
\hline \multirow[t]{2}{*}{ Complexity } & 1) Number of recitals & 309 & 33.60 & 22.34 & 5 & 173 \\
\hline & 2) Number of Eurovoc words & 309 & 6.15 & 1.79 & 1 & 13 \\
\hline \multirow[t]{3}{*}{ Conflict in the Council } & $\begin{array}{l}\text { left-right Council range: absolute difference between right-left pivots in } \\
\text { the Council }\end{array}$ & 309 & 2.69 & 0.97 & 0.29 & 5.08 \\
\hline & $\begin{array}{l}\text { Integration Council range: absolute difference between pro- and } \\
\text { antiintegration pivots in the Council }\end{array}$ & 309 & 1.94 & 1.70 & 0.01 & 6.93 \\
\hline & Robustness check: Number B items & 309 & 1.47 & 1.63 & 0 & 12 \\
\hline Decision rules & Laws adopted by QMV & 309 & 0.82 & 0.38 & 0 & 1 \\
\hline Codecision & Laws adopted by Codecision & 309 & 0.69 & 0.46 & 0 & 1 \\
\hline \multirow[t]{2}{*}{ Council-EP conflict } & $\begin{array}{l}\text { Council-EP proximity- } \mathrm{l}-\mathrm{r} \\
\text { absolute value of the difference between the median EP and the } \\
\text { Council Pivot- }\end{array}$ & 309 & 1.26622 & 0.7478669 & 0.0782356 & 3.654422 \\
\hline & $\begin{array}{l}\text { Council-EP proximity- integration: absolute value of the difference } \\
\text { between the median EP and the Council Pivot- }\end{array}$ & 309 & 3.579159 & 1.66851 & 0.0116402 & 6.9292 \\
\hline Amending laws & Amending legislation & 309 & 0.26 & 0.44 & 0 & 1 \\
\hline Salience & $\begin{array}{l}\text { Frequency of topics in Council Conclusions (Comparative agenda } \\
\text { Project) }\end{array}$ & 300 & 97.59 & 107.92 & 0 & 593 \\
\hline Supranational integration & Leuffen et. al measurement & 309 & 3.27 & 0.94 & 0 & 5 \\
\hline \multirow[t]{3}{*}{ Interinstitutional conflict } & 1) Acts adopted on first reading & 214 & 0.39 & 0.49 & 0 & 1 \\
\hline & 2) Conflict Council-median Commissioner (left-right) & 309 & 1.29 & 0.94 & 0.06 & 4 \\
\hline & 3) Conflict Council-median Commissioner (integration) & 309 & 1.74 & 1.62 & 0.05 & 9.2 \\
\hline
\end{tabular}


Table 5. Determinants of delegation choice

\begin{tabular}{|c|c|c|c|}
\hline & All Laws & Other Procedures & Codecision \\
\hline DV = Delegation Path & Model I & Model II & Model III \\
\hline QMV & $1.264^{\star \star \star}(0.391)$ & $1.904(1.327)$ & \\
\hline Complexity (policy dimensions) & $0.172^{\star *}(0.0698)$ & $0.230(0.174)$ & $0.158^{*}(0.0812)$ \\
\hline Complexity (recitals) & $0.0244^{* \star *}(0.00661)$ & $0.0288(0.0261)$ & $0.0250^{* * *}(0.00725)$ \\
\hline Supranational integration & $0.549(0.677)$ & $-1.369(1.002)$ & $3.167^{\star \star}(1.329)$ \\
\hline $\begin{array}{l}\text { Supranational integration * } \\
\text { Supranational integration }\end{array}$ & $-0.109(0.118)$ & $0.254(0.199)$ & $-0.535^{\star \star}(0.215)$ \\
\hline Salience & $-0.00155(0.00134)$ & $-0.0141^{\star \star \star}(0.00465)$ & $0.00120(0.00151)$ \\
\hline Amending & $-0.438(0.276)$ & $-0.156(0.786)$ & $-0.429(0.307)$ \\
\hline Economic regulation & $0.0531(0.285)$ & $0.956(0.619)$ & $-0.133(0.349)$ \\
\hline $\begin{array}{l}\text { Interinstitutional conflict } \\
\text { (integration) }\end{array}$ & & $0.242(0.294)$ & \\
\hline $\begin{array}{l}\text { Interinstitutional conflict (left- } \\
\text { right) }\end{array}$ & & $0.200(0.316)$ & \\
\hline $\begin{array}{l}\text { Inter-institutional conflict (early } \\
\text { agreement) }\end{array}$ & & & $-0.616^{\star}(0.345)$ \\
\hline Observations & 300 & 95 & 205 \\
\hline Pseudo $R^{2}$ & 0.096 & 0.234 & 0.081 \\
\hline
\end{tabular}

Ordered Logistic Regression with Treaty Fixed Effect (omitted from table). Standard errors in parentheses. Legend: * $\mathrm{p}<0.1,{ }^{\star \star} \mathrm{p}<0.05,{ }^{\star \star \star} \mathrm{p}<0.01$.

significant effect for laws adopted only by the Council. In these cases, the more salient the policy area is, the more likely legislation delegates to national administrations. This finding is interesting because salience seems to be the only factor affecting delegation choices when the Council is the only principal. It suggests that when the Council has the power to decide by itself, it systematically favours more national control over policy implementation in the case of high political salience, all other things being equal. However, this mechanism does not seem to apply when the European Parliament is involved. Given that the measurement I use for salience is the importance attached to policy issues in the Council agenda, it may be the case that under codecision issues that are salient to the Council are counter-balanced by the priorities of the Parliament. Finally, under codecision, early agreements seem to slightly increase the likelihood of opting for a national implementation path, while decreasing the likelihood of the shared one.

\section{Relative discretion}

I now test my hypotheses accounting for varying degrees of relative discretion (Hypotheses 4 and 5) by means of multivariate OLS regression analysis, given that my second dependent variable is continuous. I report four models. I distinguish between acts adopted under codecision and acts adopted under other procedures, and I also control for complexity as it might as well affect discretion granted of implementers. 
Table 6. Determinants of the Commission's relative discretion

\begin{tabular}{|c|c|c|c|c|}
\hline \multirow{2}{*}{$\begin{array}{l}\text { DV }=\text { Commission } \\
\text { Relative Discretion }\end{array}$} & \multicolumn{2}{|c|}{ Other Procedures } & \multicolumn{2}{|c|}{ Codecision } \\
\hline & Model I & Model II & Model III & Model IV \\
\hline QMV & $20.82^{\star \star}(9.273)$ & $8.259(13.14)$ & & \\
\hline Economic Regulation & $7.732^{\star \star}(3.059)$ & $7.571^{\star \star}(3.069)$ & $0.164(1.962)$ & $0.808(1.999)$ \\
\hline $\begin{array}{l}\text { Council conflict (left- } \\
\text { right) }\end{array}$ & $5.835^{\star \star}(2.539)$ & $5.416^{\star \star}(2.671)$ & & \\
\hline $\begin{array}{l}\text { Council conflict } \\
\text { (integration) }\end{array}$ & $0.970(1.640)$ & $-8.369(6.156)$ & & \\
\hline Salience & $-0.0281^{\star}(0.0143)$ & $-0.0339^{\star \star}(0.0165)$ & $\begin{array}{l}0.00566 \\
(0.00864)\end{array}$ & $\begin{array}{l}0.00679 \\
(0.00868)\end{array}$ \\
\hline $\begin{array}{l}\text { Complexity (policy } \\
\text { dimensions) }\end{array}$ & $0.418(0.711)$ & $0.707(0.855)$ & $0.0990(0.470)$ & $\begin{array}{l}0.0994 \\
(0.468)\end{array}$ \\
\hline Complexity (recitals) & $0.0761(0.144)$ & $0.0776(0.147)$ & $0.0165(0.0314)$ & $\begin{array}{l}0.00930 \\
(0.0313)\end{array}$ \\
\hline Amending & $-0.623(4.883)$ & $-0.237(4.655)$ & $0.529(1.792)$ & $0.785(1.785)$ \\
\hline $\begin{array}{l}\text { Interinstitutional } \\
\text { conflict (integration) }\end{array}$ & & $8.162(5.178)$ & & \\
\hline $\begin{array}{l}\text { Interinstitutional } \\
\text { conflict (left-right) }\end{array}$ & & $0.593(1.560)$ & & \\
\hline $\begin{array}{l}\text { Council EP conflict } \\
\text { (left-right) }\end{array}$ & & & $-1.879(1.320)$ & $-2.044(1.321)$ \\
\hline $\begin{array}{l}\text { Council EP conflict } \\
\text { (integration) }\end{array}$ & & & $-0.167(1.160)$ & $-0.478(1.188)$ \\
\hline Early agreement & & & & $-2.861(1.870)$ \\
\hline Constant & $-43.03^{\star \star \star}(14.92)$ & $-28.06(19.92)$ & $-7.869(6.674)$ & $-6.412(6.830)$ \\
\hline Observations & 95 & 95 & 205 & 205 \\
\hline$R^{2}$ & 0.252 & 0.273 & 0.035 & 0.045 \\
\hline
\end{tabular}

Multivariate OLS regression with Treaty fixed effects. Robust standard errors in parentheses. Legend: * $p<0.1$, ** $\mathrm{p}<0.05,{ }^{\star \star *} \mathrm{p}<0.01$.

First of all, as shown in Figure 7, QMV grants on average more discretion to the Commission vis-à-vis national administrations, both significance and effect are quite strong, given that shifting from unanimity to QMV increases the Commission's relative discretion, by on average $120 \%$. Hence, not only QMV produces a higher likelihood of opting for more supranational agents, it also increases the discretion of the Commission vis-à-vis national administrations.

Regarding conflict, Model 1 supports Hypothesis 5 by showing that with the increase in conflict among Council members on the left-right dimension (the integration one is not significant), higher discretion is granted to the Commission. On average, one standard deviation increase in both left-right and integration conflict increases the Commission's relative discretion by about $40 \%$, as displayed in Figure 8.

Regarding the conflict between the Council and the European Parliament under codecision, the results are not statistically significant. Yet, the direction of the 

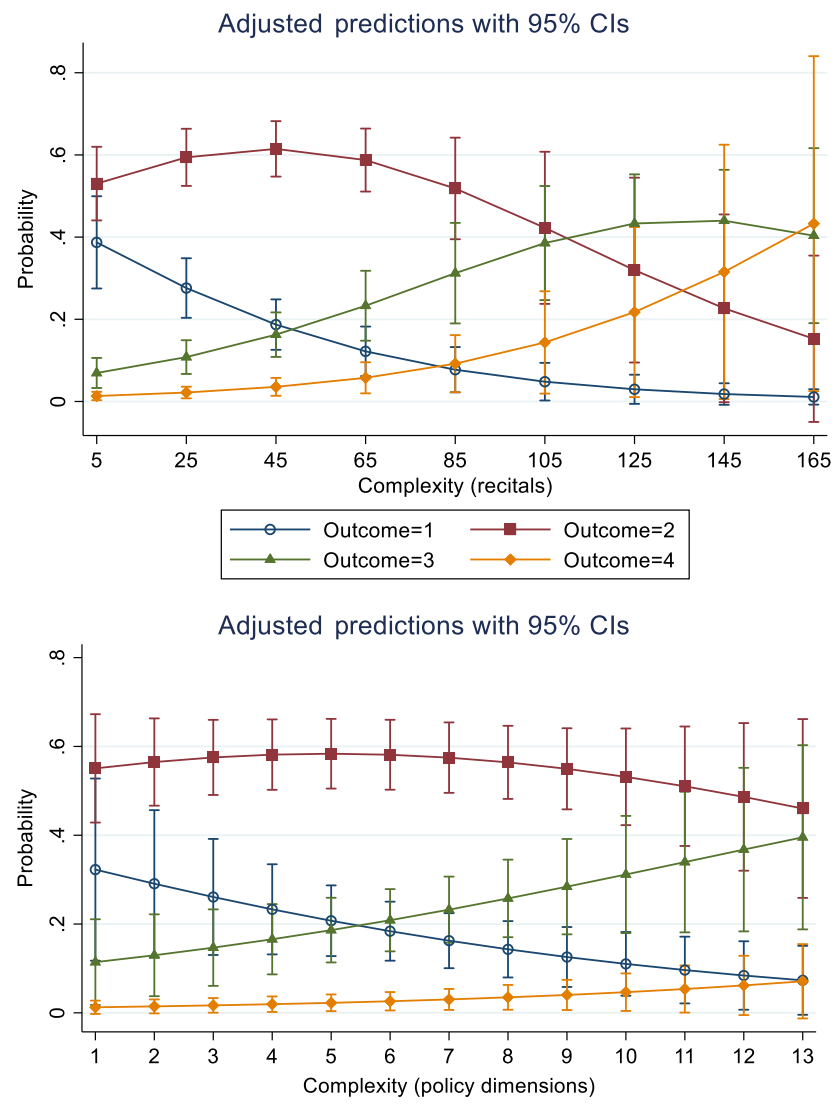

Figure 5. Effect of complexity on probability of agent selection.

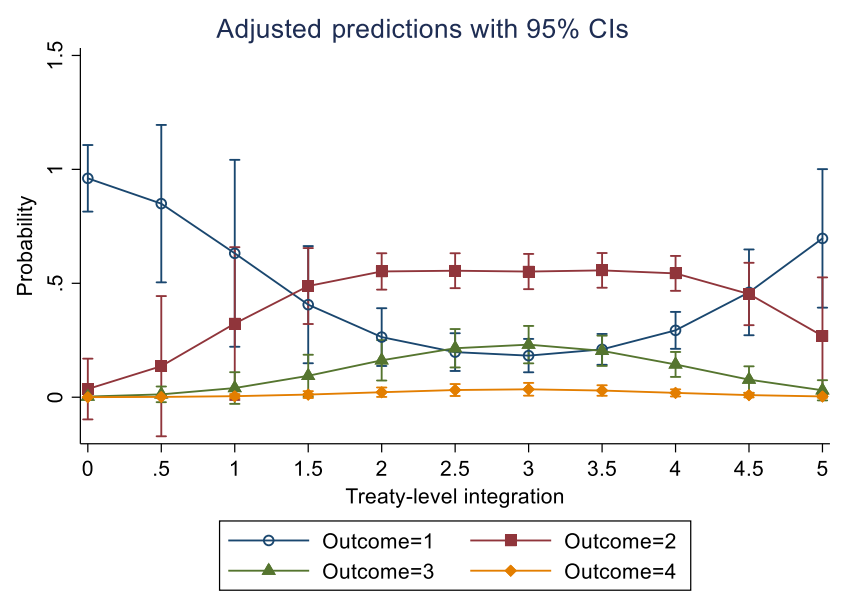

Figure 6. Effect of treaty-level integration on probability of agent selection. 


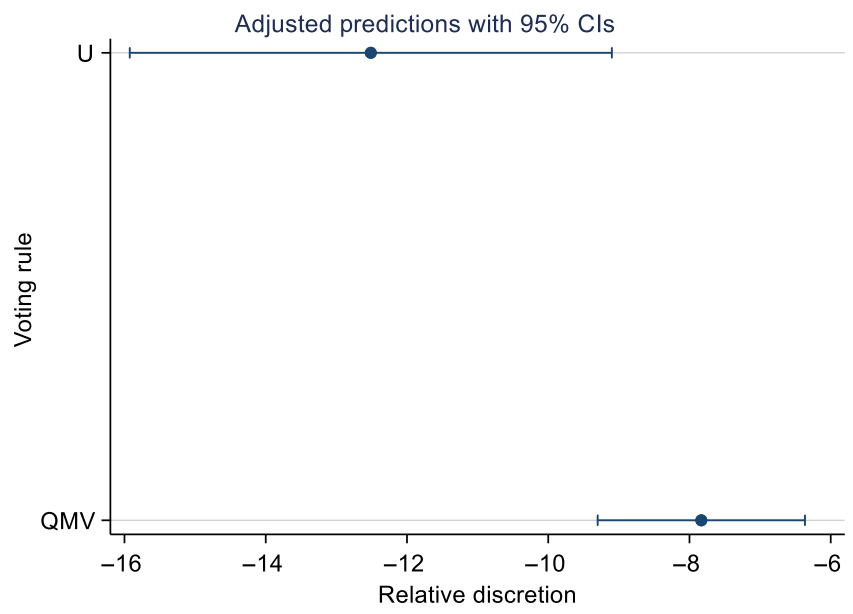

Figure 7. Effect of QMV on relative discretion.

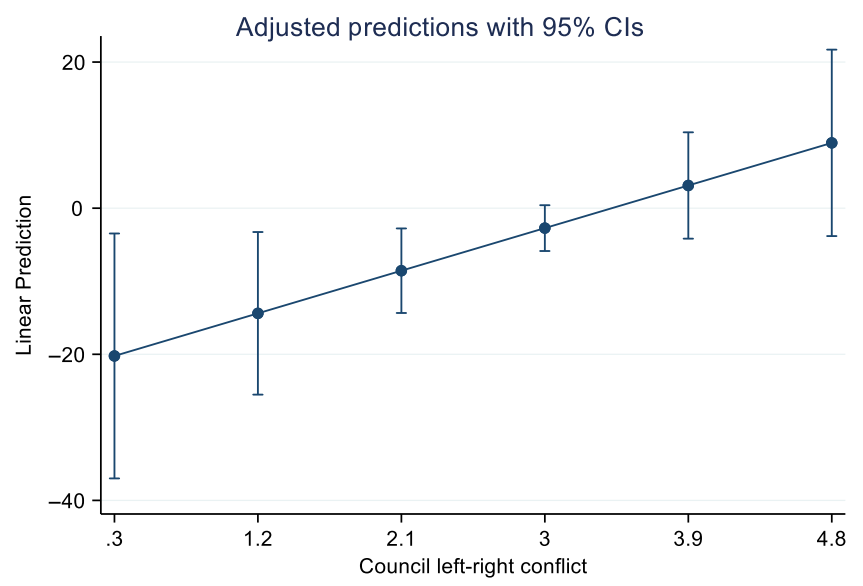

Figure 8. Effect of conflict in the Council on the Commission's relative discretion.

relationship contradicts Hypothesis 5. Indeed, it seems that higher conflict between the EP and the Council leads, on average, to lower relative discretion for the Commission favouring, therefore, national administrations for policy implementation. The reason underlying this negative association may deserve further investigation. For example, Gastinger and Adriaensen (2019) suggest that delegation dynamics when the EP is involved in the negotiating process may be affected by the interaction between the European Parliament and citizens/civil society. Finally, similar to the previous empirical analysis, the results show that salient laws grant on average less discretion to the Commission than to national administrations. The effect is significant when all laws are included as well as when the Council is the only principal, while it loses significance under codecision. 


\section{Discussion}

Throughout this article, I have mapped delegation paths and agents' discretion in EU secondary legislation in the post-Maastricht era, on the basis of a data set embracing this period up to 2016. As much as description per se does not provide causal explanation, this step was useful for the purposes of a subsequent investigation of why specific delegation choices occur and how much agent control is associated with them. Assessing why principals opt for different degrees of supranational implementation was the second step of the empirical analysis. Following a PA framework, I have argued in favour of functional logics (complexity) and path dependence (degree of previous integration). Indeed, complexity is a strong predictor of the choice of involving agencies and the Commission, more than just national administrations and the Commission, or just national administrations. Although national administrations may be generally endowed with more resources than the Commission and agencies, supranational actors are increasingly involved as the complexity increases. Another interesting finding relates to the degree of integration in the EU treaties. This latter is associated with agent selection in a curvilinear way. This is especially relevant in view of the recent new intergovernmentalist literature (Bickerton et al. 2015), supporting the view of integration without supranationalisation as the curvilinear trend may point to a decreasing willingness to grant authority to the supranational level over time and across policy. However, the result leaves unanswered why this relationship holds only for laws adopted under codecision.

In my analysis, I have also taken pooling into account as a major determinant of supranational delegation, which is partly confirmed by the results, suggesting that QMV keeps working as a "commitment technology" (Franchino 2007, p. 187), ensuring higher supranational delegation and discretion.

As far as discretion is concerned, one result confirms previous findings and another opens a scholarly debate. When the Council is the only principal, conflict among Council members shapes delegation choices so as to have higher supranational discretion. However, when the European Parliament is involved, the Commission appears to be granted relatively lower discretion when the Council and the Parliament display more heterogeneous preferences. This may depend on the preference divergence between the Commission and principals, combined with the relative bargaining power of the two legislators. Future research might want to expand research in this field through in-depth case studies along the lines of da Conceição-Heldt (2017) and Gastinger and Adriaensen (2019).

Lastly, the results of the effect of salience are interesting, as the Council seems to be less willing to grant supranational delegation and discretion when issues are high on its agenda.

Where does implementation lie, then, and why? This study shows that the copresence of multiple actors that together participate in the implementation of EU policies is subjected to impressive variation. The PA approach explains the choice of going more or less supranational as a response to functional necessities as well as previous delegation decisions, but that delegation to supranational institutions may be halted by political dynamics connected to the broader process of EU integration. Supranational leeway in turn is favoured 
by conflict within the Council. Yet, the relevance of this finding is somewhat limited by the fact that in the past 10 years the European Parliament has been colegislator and is increasing its influence (Costello and Thomson 2013). For this reason, the impact of the conflict between Parliament and the Council bears growing interest and should enjoy more space in the future research on delegation.

Finally, the explanatory power of the study presents a limitation, as the sample size may be considered small in comparison with the whole EU legislative output. In order to further increase the robustness and reliability of these findings, future research could extend the investigation to a much wider body of legislation by employing methodologies allowing a swifter extraction of delegation relationships from legal acts. For example, recent scholarly works by Shaffer (2020) and Anastasopoulos and Bertelli (2020) offer promising research avenues, through the application of natural language processing and machine learning techniques to the analysis, respectively, of the United States and EU legislation.

Supplementary material. To view supplementary material for this article, please visit https://doi.org/10. 1017/S0143814X20000100.

Acknowledgements. I wish to thank Fabio Franchino, Camilla Mariotto, Christian Rauh, Hussein Kassim, Marcello Carammia, Mattia Guidi and three anonymous referees for their precious feedback on previous versions of this article.

Data Availability Statement. Replication materials are available at https://dataverse.harvard.edu/dataset. xhtml?persistentId=doi:10.7910/DVN/JVLKNW

\section{References}

Anastasopoulos LJ and Bertelli AM (2020) Understanding Delegation Through Machine Learning: A Method and Application to the European Union. American Political Science Review, 114(1), 291-301. https://doi.org/10.1017/S0003055419000522

Bergman T (2000. The European Union as the next step of delegation and accountability. European Journal of Political Research, 37(3), 415-429. https://doi.org/10.1111/1475-6765.00520

Bickerton CJ, Hodson D and Puetter U (2015) The New Intergovernmentalism: European Integration in the Post-Maastricht Era. JCMS: Journal of Common Market Studies, 53(4), 703-722. https://doi.org/10. $1111 /$ jcms. 12212

Blauberger M and Rittberger B (2015) Conceptualizing and theorizing EU regulatory networks. Regulation \& Governance, 9(4), 367-376. https://doi.org/10.1111/rego.12064

Börzel TA (2005) Mind the gap! European integration between level and scope. Journal of European Public Policy, 12(2), 217-236. https://doi.org/10.1080/13501760500043860

Busuioc M and Groenleer M (2013) Beyond Design: The Evolution of Europol and Eurojust. Perspectives on European Politics and Society, 14(3), 285-304. https://doi.org/10.1080/15705854.2013.817803

Calvert RL, McCubbins MD and Weingast BR (1989) A Theory of Political Control and Agency Discretion. American Journal of Political Science, 33(3), 588-611. https://doi.org/10.2307/2111064

Chiti E (2004) Decentralisation and Integration into the Community Administrations: A New Perspective on European Agencies. European Law Journal, 10(4), 402-438. https://doi.org/10.1111/j.1468-0386.2004. 00223.x

Costello R and Thomson R (2013) The Distribution of Power Among EU Institutions: Who Wins Under Codecision and Why? Journal of European Public Policy, 20(7), 1025-1039. https://doi.org/10.1080/ 13501763.2013.795393

Crombez C and Hix S (2015) Legislative Activity and Gridlock in the European Union. British Journal of Political Science, 45(3), 477-499. https://doi.org/10.1017/S0007123413000380 
Curtin D (2009) Delegation to EU Non - Majoritarian Agencies and Emerging Practices of Public Accountability. https://papers.ssrn.com/sol3/papers.cfm?abstract_id=1349771\&download=yes

da Conceição E (2010) Who Controls Whom? Dynamics of Power Delegation and Agency Losses in EU Trade Politics. JCMS: Journal of Common Market Studies, 48(4), 1107-1126. https://doi.org/10.1111/j. 1468-5965.2010.02086.x.

da Conceição-Heldt E (2017) Multiple Principals' Preferences, Types of Control Mechanisms and Agent's Discretion in Trade Negotiations. In Delreux T. and Adriaensen J. (eds.), The Principal Agent Model and the European Union. Springer International Publishing. https://doi.org/10.1007/978-3-319-55137-1_9

Däubler T, Benoit K, Mikhaylov S and Laver M (2012) Natural Sentences as Valid Units for Coded Political Texts. British Journal of Political Science, 42(4), 937-951. https://doi.org/10.1017/ S0007123412000105

Delreux T (2009) The EU Negotiates Multilateral Environmental Agreements: Explaining the Agent's Discretion. Journal of European Public Policy, 16(5), 719-737. https://doi.org/10.1080/ 13501760902983432

Delreux T and Adriaensen J (2017) Introduction. Use and Limitations of the Principal-Agent Model in Studying the European Union. In Delreux T. and Adriaensen J. (eds.), The Principal Agent Model And The European Union. Springer International Publishing, 1-34. https://doi.org/10.1007/978-3-319-551371_1

Delreux T and Adriaensen J (2018) Twenty Years of Principal-Agent Research in EU Politics: How to Cope with Complexity? European Political Science, 17(2), 258-275. https://doi.org/10.1057/s41304-017-0129-4

Döring H and Manow P (2012) Parliament and government composition database (ParlGov). An Infrastructure for Empirical Information on Parties, Elections and Governments in Modern Democracies. Version, 12(10).

Döring H and Manow P (2016) Parliaments and governments database (ParlGov): Information on parties, elections and cabinets in modern democracies. Development Version.

Dunlop CA and James O (2007) Principal-Agent Modelling and Learning: The European Commission, Experts and Agricultural Hormone Growth Promoters. Public Policy and Administration, 22(4), 403422. https://doi.org/10.1177/0952076707081585

Eberlein B and Grande E (2005) Beyond Delegation: Transnational Regulatory Regimes and the EU Regulatory State. Journal of European Public Policy, 12(1), 89-112.

Egan Nugent and Peterson. (2017) The Principal Agent Model And The European Union. Berlin Heidelberg: Springer.

Egeberg M and Trondal J (2017) Researching European Union Agencies: What Have We Learnt (and Where Do We Go from Here)? JCMS: Journal of Common Market Studies, 55(4), 675-690. https:// doi.org/10.1111/jcms.12525

Elgie R (2002) The Politics of the European Central Bank: Principal-Agent Theory and the Democratic Deficit. Journal of European Public Policy, 9(2), 186-200. https://doi.org/10.1080/13501760110120219

Elgie R and McMenamin I (2005) Credible Commitment, Political Uncertainty or Policy Complexity? Explaining Variations in the Independence of Non-Majoritarian Institutions in France. British Journal of Political Science, 35(3), 531-548.

Elsig M (2010) European Union Trade Policy After Enlargement: Larger Crowds, Shifting Priorities and Informal Decision-Making. Journal of European Public Policy, 17(6), 781-798. https://doi.org/10. 1080/13501763.2010.486975

Epstein D and O'Halloran S (1994) Administrative Procedures, Information, and Agency Discretion. American Journal of Political Science, 38(3), 697-722.

Epstein D and O'Halloran S (1999) Delegating Powers: A Transaction Cost Politics Approach To Policy Making Under Separate Powers. Cambridge University Press.

Ershova A (2019) The Watchdog or the Mandarin? Assessing the Impact of the Directorates General on the EU Legislative Process. Journal of European Public Policy, 26(3), 407-427. https://doi.org/10.1080/ 13501763.2018.1447009

Fabbrini S and Puetter U (2016) Integration without supranationalisation: studying the lead roles of the European Council and the Council in post-Lisbon EU politics. Journal of European Integration, 38(5), 481-495. https://doi.org/10.1080/07036337.2016.1178254

Featherstone K and Radaelli C M (Eds.) (2003) The Politics Of Europeanization. Oxford: Oxford University Press. 
Franchino F (2002) Efficiency or Credibility? Testing the Two Logics of Delegation to the European Commission. Journal of European Public Policy, 9(5), 677-694. https://doi.org/10.1080/ 13501760210162302

Franchino F (2007a). The Powers Of The Union: Delegation In The EU. Cambridge University Press.

Franchino F (2007b). The Powers Of The Union: Delegation In The EU. Cambridge University Press.

Gastinger M and Adriaensen J (2019) Of Principal(s') Interest? A Disaggregated, Multiple Principals' Approach to Commission Discretion. JCMS: Journal of Common Market Studies, 57(2), 353-370. https://doi.org/10.1111/jcms.12801

Hartlapp M, Metz J and Rauh C (2014) Which Policy For Europe?: Power And Conflict Inside The European Commission. Oxford University Press. https:/www.oxfordscholarship.com/view/10.1093/acprof:oso/ 9780199688036.001.0001/acprof-9780199688036

Hawkins DG, Lake DA, Nielson DL and Tierney MJ (2006) Delegation and Agency in International Organizations. 426.

Hix S and Høyland B (2011) The Political System of the European Union, 3rd ed. Basingstoke: Palgrave Macmillan.

Hooghe L and Marks G (2001) Multi-Level Governance And European Integration. Rowman \& Littlefield.

Hooghe L and Marks G (2003) Unraveling the Central State, But How? Types of Multi-Level Governance. The American Political Science Review, 97(2), 233-243. JSTOR.

Hooghe L and Marks G (2009) A Postfunctionalist Theory of European Integration: From Permissive Consensus to Constraining Dissensus. British Journal of Political Science, 39(1), 1-23. https://doi.org/ $10.1017 /$ S0007123408000409

Hooghe L and Marks G (2015) Delegation and Pooling in International Organizations. The Review of International Organizations, 10(3), 305-328. https://doi.org/10.1007/s11558-014-9194-4

Kaeding M (2006) Determinants of Transposition Delay in the European Union. Journal of Public Policy, 26(3), 229-253.

Kassim H and Menon A (2003) The Principal-Agent Approach and the Study of the European Union: Promise Unfulfilled? Journal of European Public Policy, 10(1), 121-139.

Kelemen RD and Tarrant AD (2011) The Political Foundations of the Eurocracy. West European Politics, 34(5), 922-947. https://doi.org/10.1080/01402382.2011.591076

Kerremans B (2004) Principal (s) versus agent: an analysis of the impact of member states' control on the Commission's behaviour as trade policy entrepreneur in WTO negotiations. IIEB Working Papers, 3.

Kiewiet DR and McCubbins MD (1991) The Logic Of Delegation. University of Chicago Press.

Klingemann H-D, Volkens A, Bara J, Budge I and McDonald MD (2006) Mapping Policy Preferences II: Estimates For Parties, Electors, And Governments In Eastern Europe, European Union, And OECD 19902003. Oxford University Press.

Kroll DA (2017) Manifest and Latent Control on the Council by the European Council. In T. Delreux \& J. Adriaensen (Eds.), The Principal Agent Model And The European Union. Springer International Publishing. 157-180. https://doi.org/10.1007/978-3-319-55137-1_7

Leuffen D, Rittberger B and Schimmelfennig F (2013) Differentiated Integration. Education, UK: Macmillan. https://doi.org/10.1007/978-1-137-28501-0

Levi-Faur D (2011) Regulatory Networks and Regulatory Agencification: Towards a Single European Regulatory Space. Journal of European Public Policy, 18(6), 810-829. https://doi.org/10.1080/ 13501763.2011.593309

Lindberg LNS (1970) Europe's Would-Be Polity: Patterns of Change in the European Community. Prentice-Hall.

Majone G (1994) The Rise of the Regulatory State in Europe. West European Politics, 17(3), 77-101.

Majone G (1997) From the Positive to the Regulatory State: Causes and Consequences of Changes in the Mode of Governance. Journal of Public Policy, 17(2), 139-167. JSTOR.

Majone G (2001) Two Logics of Delegation: Agency and Fiduciary Relations in EU Governance. European Union Politics, 2(1), 103-122. https://doi.org/10.1177/1465116501002001005

Maricut A (2016) With and Without Supranationalisation: The Post-Lisbon Roles of the European Council and the Council in Justice and Home Affairs Governance. Journal of European Integration, 38(5), 541555. https://doi.org/10.1080/07036337.2016.1178253

Martin LL (2006, September). Distribution, information, and delegation to international organizations: the case of IMF conditionality. Delegation and Agency in International Organizations. https://doi.org/10. 1017/CBO9780511491368.006 
McCubbins Mathew D and Schwartz T (1984) Congressional Oversight Overlooked: Police Patrols versus Fire Alarms. American Journal of Political Science, 28(1), 165-179. https://doi.org/10.2307/2110792

McCubbins Matthew D, Noll RG and Weingast BR (1989) Structure and Process, Politics and Policy: Administrative Arrangements and the Political Control of Agencies. Virginia Law Review, 75(2), 431-482. https://doi.org/10.2307/1073179

McCubbins MD and Sullivan T (Eds.). (1987) Congress: Structure And Policy. Cambridge University Press.

Michaelowa K, Reinsberg B and Schneider CJ (2018) The Politics of Double Delegation in the European Union. International Studies Quarterly, 62(4), 821-833. https://doi.org/10.1093/isq/sqy034

Migliorati M (2017) The Commission as a Network Orchestrator in EU Multi-Level Governance? The Case of the European Union Network for the Implementation and Enforcement of Environmental Law (IMPEL) (SSRN Scholarly Paper ID 2958140). Social Science Research Network. https://papers.ssrn.com/ abstract $=2958140$

Migliorati M (2019) Relying on Agencies in Major European Union Legislative Measures. West European Politics, 0(0), 1-22. https://doi.org/10.1080/01402382.2019.1602336

Mikhaylov S, Laver M and Benoit KR (2012) Coder Reliability and Misclassification in the Human Coding of Party Manifestos. Political Analysis, 20(01), 78-91. https://doi.org/10.1093/pan/mpr047

Moravcsik A (1993) Preferences and Power in the European Community: A Liberal Intergovernmentalist Approach. JCMS: Journal of Common Market Studies, 31(4), 473-524. https://doi.org/10.1111/j.14685965.1993.tb00477.x

Moury C and Héritier A (2012) Shifting Competences and Changing Preferences: The Case of Delegation to Comitology. Journal of European Public Policy, 19(9), 1316-1335. https://doi.org/10.1080/13501763. 2012.677189

Nielson DL and Tierney MJ (2003) Delegation to International Organizations: Agency Theory and World Bank Environmental Reform. International Organization, 57(2), 241-276. JSTOR.

Pollack MA (1997) Delegation, Agency, and Agenda Setting in the European Community. International Organization, 51(1), 99-134. https://doi.org/10.1162/002081897550311

Pollack MA (2003) The Engines of European Integration: Delegation, Agency and Agenda Setting in the EU. Oxford University Press.

Rasmussen A and Reh C (2013) The Consequences of Concluding Codecision Early: Trilogues and IntraInstitutional Bargaining Success. Journal of European Public Policy, 20(7), 1006-1024. https://doi.org/10. 1080/13501763.2013.795391

Rauh C (2019) EU Politicization and Policy Initiatives of the European Commission: The Case of Consumer Policy. Journal of European Public Policy, 26(3), 344-365. https://doi.org/10.1080/13501763.2018. 1453528

Ripoll Servent A (2018) A New Form of Delegation in EU Asylum: Agencies as Proxies of Strong Regulators. JCMS: Journal of Common Market Studies, 56(1), 83-100. https://doi.org/10.1111/jcms.12652

Rittberger B, Schwarzenbeck H and Zangl B (2017) Where Does the Buck Stop? Explaining Public Responsibility Attributions in Complex International Institutions. JCMS: Journal of Common Market Studies, 55(4), 909-924. https://doi.org/10.1111/jcms.12524

Saurugger S and Radaelli CM (2008) The Europeanization of Public Policies: Introduction. Journal of Comparative Policy Analysis: Research and Practice, 10(3), 213-219. https://doi.org/10.1080/ 13876980802276847

Scharpf FW (1997) Introduction: The Problem-Solving Capacity of Multi-Level Governance. Journal of European Public Policy, 4(4), 520-538. https://doi.org/10.1080/135017697344046

Schneider CJ and Tobin JL (2013) Interest Coalitions and Multilateral Aid Allocation in the European Union. International Studies Quarterly, 57(1), 103-114. https://doi.org/10.1111/isqu.12062

Shaffer R (2020) Power in Text: Implementing Networks and Institutional Complexity in American Law.

Tallberg J (2002) Delegation to Supranational Institutions: Why, How, and with What Consequences? West European Politics, 25(1), 23-46. https://doi.org/10.1080/713601584

Thaler P (2016) The European Commission and the European Council: Coordinated Agenda Setting in European Energy Policy. Journal of European Integration, 38(5), 571-585. https://doi.org/10.1080/ 07036337.2016.1178252

Thatcher M (2002) Delegation to Independent Regulatory Agencies: Pressures, Functions and Contextual Mediation. West European Politics, 25(1), 125-147. https://doi.org/10.1080/713601588 
Thatcher M (2011) The Creation of European Regulatory Agencies and its Limits: A Comparative Analysis of European Delegation. Journal of European Public Policy, 18(6), 790-809. https://doi.org/10.1080/ 13501763.2011.593308

Thatcher M and Sweet AS (2002) Theory and Practice of Delegation to Non-Majoritarian Institutions. West European Politics, 25(1), 1-22. https://doi.org/10.1080/713601583

Thomson $\mathbf{R}$ and Torenvlied $\mathbf{R}$ (2011) Information, Commitment and Consensus: A Comparison of Three Perspectives on Delegation in the European Union. British Journal of Political Science, 41(1), 139-159. http://dx.doi.org.pros.lib.unimi.it/10.1017/S0007123410000268

Toshkov D (2008) Embracing European Law: Compliance with EU Directives in Central and Eastern Europe. European Union Politics, 9(3), 379-402. https://doi.org/10.1177/1465116508093490

Volden C (2002) A Formal Model of the Politics of Delegation in a Separation of Powers System. American Journal of Political Science, 46(1), 111-133. https://doi.org/10.2307/3088417

Warntjen A (2012) Measuring Salience in EU Legislative Politics, Measuring Salience in EU Legislative Politics. European Union Politics, 13(1), 168-182. https://doi.org/10.1177/1465116511428495

Wilkerson J, Baumgartner FR, Brouard S, Chaqués L, Green-Pedersen C, Grossman E, Jones BD, Timmermans A and Walgrave S (2009) The Comparative Agenda Project: Objectives and Content. Revue internationale de politique comparée, 16(3), 365-379.

Wonka A and Rittberger B (2010) Credibility, Complexity and Uncertainty: Explaining the Institutional Independence of 29 EU Agencies. West European Politics, 33(4), 730-752. https://doi.org/10.1080/ 01402381003794597

Yesilkagit K and Christensen JG (2010) Institutional Design and Formal Autonomy: Political versus Historical and Cultural Explanations. Journal of Public Administration Research and Theory, 20(1), 53-74. https://doi.org/10.1093/jopart/mup002

Zulianello M (2014) Analyzing Party Competition Through the Comparative Manifesto Data: Some Theoretical and Methodological Considerations. Quality \& Quantity, 48(3), 1723-1737. https://doi. org/10.1007/s11135-013-9870-0

Cite this article: Migliorati M (2021). Where does implementation lie? Assessing the determinants of delegation and discretion in post-Maastricht European Union. Journal of Public Policy 41, 489-514. https://doi.org/10.1017/S0143814X20000100 